\title{
Society, Government, and the Political System
}

\section{Andreas Ladner}

\subsection{INTRODUCTION}

Switzerland, at least by the commonly used measures (GDP, competition, and innovation rankings), is a very successful and prosperous country. Its residents esteem Swiss political institutions and trust the authorities, and they are content with the range of services Swiss governments provide. In Europe, along with the Scandinavians, the Swiss are among the most satisfied with their national government and with the functioning of their democracy. ${ }^{1}$ An important contribution to this esteem comes from an effective and well-functioning public administration.

The organization, functioning, and performance of public administrative bodies are directly linked to government configurations, political institutions, and the key values which undergird them. These frameworks set the conditions under which public administration works, along with

${ }^{1}$ See the European Social Survey (ESS5-2010, ed.2.0; own calculations), and Denters et al. (2016).

A. Ladner $(\bowtie)$

IDHEAP, University of Lausanne, Lausanne, Switzerland e-mail: andreas.ladner@unil.ch

(C) The Author(s) 2019

A. Ladner et al. (eds.), Swiss Public Administration, Governance and Public Management, https://doi.org/10.1007/978-3-319-92381-9_1 
the goals or directions, pursued. Knowledge of the basic principles of a political system, the institutional configuration, and the values underlying the system and the institutions are key to understanding, and analysing, a public administration.

Without meaning to invoke historical determinism, the genesis of the governmental structures in the country gives insights into the reasons for its current organization and reveals the principles and ideas guiding it. This helps to understand the limits or prospects for making administrative adjustments or carrying out reforms. Of particular interest is the question of how malleable governmental institutions are. To what extent is the organization of a government determined by the past (path dependency)? To what extent do structural and cultural factors (such as small size or the differences between language regions or religious faiths) play a role? To what extent might changes and adjustments be the result of conscious agenda-setting and political decisions taken (for more on this, see Ladner 2011) ? $?^{2}$

We begin by briefly looking at the foundation of governmental structures in Switzerland and their subsequent expansion. We then turn to its most important structural and cultural characteristic and the basic elements of the political system. In doing so, we refer to the effects this institutional, political, and historical framework has, and has had, on how Swiss public administration functions.

\subsection{From Confederation to Federal State: BotTom-Up NATION-BUILDing}

The key to understanding the Swiss state and its institutions is the fact that it developed from the bottom up. Unlike in countries with a monarchical past, a strong, centralized government never existed on Swiss soil, or at least not prior to the founding of the modern Swiss state in 1848. The history of the country as an independent political entity instead began with a loose alliance between a few rural cantons gradually joined by other cantons. This alliance acquired, controlled, and exploited various territories which now form modern Switzerland.

It was only with Napoleon's occupation and the subsequent creation of the Helvetic Republic (1798-1802) that cantons were put on an equal footing and a national, centralized administration was introduced.

\footnotetext{
${ }^{2}$ These are precisely the questions raised by various 'neo-institutionalist' approaches.
} 
However, the re-organization of the country on the French model was only a brief historical interlude, and the country soon reverted to earlier habits, though with the difference that the sovereignty of the individual cantons was now no longer questioned. The Congress of Vienna in 1815 set the territorial boundaries of the country. This Congress also ensured Switzerland would be neutral, a status desired not just by the Swiss. The Great Powers wanted to prevent one another from trying to exert influence on what was a geopolitically significant area at the heart of Europe. In the course of the nineteenth century, the forces arguing for democratization and a modernization of government gradually gained influence.

One consequence-and one can certainly draw parallels here to the later development of the EU-was the introduction of conditions creating a unified economic area. Tolls and tariffs between cantons were repealed, ${ }^{3}$ and a common national currency was introduced. Efforts to create a modern, centrally organized national government led to a very brief civil war in 1847 (Sonderbundskrieg) which pitted liberal, business-friendly circles interested in modernizing government and society against Catholicdominated cantons and conservative forces antagonistic to centralization.

The liberal forces triumphed, and after a successful constitutional plebiscite, the modern Swiss federal state was founded in 1848. However, though the proposed constitution made concessions to the Catholic losers-who had argued for more independence for the cantons-they were not persuaded. The 1848 Constitution was turned down by clear margins in the Catholic cantons of Uri, Schwyz, Obwalden and Nidwalden, Zug, Wallis, Ticino, and Appenzell Innerrhoden. Approval of the proposed constitution was also helped along by more questionable means. To achieve the needed majority of cantons, the positive decision by Fribourg's then liberal government was counted, though it was a Catholic canton, and in the case of Lucerne, also Catholic, it was decided to count nonvoters as having voted in favour. The new constitution was therefore accepted.

Because individual cantons were reluctant to see their former competencies centralized, many powers remained reserved to the cantons, including much of the administration of justice, tax law, police, and transportation, along with control over education and the churches (Maissen

\footnotetext{
${ }^{3}$ According to the federal customs inspectorate, as of 1844 there were still about 370 customs stations at cantonal borders, of which 147 stood at the country's external borders and more than 180 were found inside the cantons (see Polli-Schönborn 2006).
} 
2010: 200 et seq.). Moreover, it was important to guarantee the cantons appropriate political influence at the national level. Institutionally, this was ensured by creating a territory-based upper house (Ständerat), to which each canton sent two representatives; its powers were equal to those exercised by the population-based lower house (Nationalrat). The cantons with small populations, many of which had been on the losing side of the 1847 Sonderbund civil war, were over-represented in this upper house. Still, when the 1848 Constitution came into force, the prior loose confederation of cantons was transformed into a federal state, and some of the competencies cantons previously had were transferred to the national level.

The new national government pursued goals which included creating an entity capable, over the longer term, of acting in a uniform manner visà-vis other nation-states, articulating and pursuing Swiss interests abroad, taking responsibility for external security, and asserting both independence and neutrality. To this were added guarantees given to promote public order and ensure domestic security, as well as a broadly formulated goal to 'promote the common welfare'; there was also a general mandate to erect 'public works' (see Maissen 2010: 202). The creation of a benefitsdisbursing welfare state at the national level, and the creation of a national consciousness, came later. But in comparative terms, Switzerland developed into a democratically organized country relatively early.

The price of unity, however, was a pronounced federalism and a weak national government. Residual competencies, meaning everything not explicitly defined as within the power of the national government, remain even today in the hands of the cantons. Every additional competence the national government is to acquire, or every new task it is to carry out, requires the approval of both voters and cantons. The Catholic and conservative opponents of a federal state thereby received a high degree of protection; with respect to the future development of the national government, it was necessary to take their concerns into account.

\subsection{Structural and Cultural Heterogeneity}

Which tasks can and should a state assume? Despite many commonalities, there are differences with respect to the tasks and challenges a state faces which depend on its size, its social and cultural composition, and its geographic circumstances. Of course, what needs to be coordinated among eight million residents is decidedly less than what it takes to coordinate a 
nation of a billion people, but it is also true that a country heterogeneous in language and religion requires greater efforts to integrate than does a more homogeneous society. And there is also the question to what degree a government wants to regulate and redistribute. Every additional regulation means more involvement and greater responsibility. This not just calls for a willingness to implement but also requires mobilizing the needed resources for the task. Political attitudes differ about social justice, along with the degree of redistribution and its consequences.

In terms of territory and population, Switzerland belongs to the smaller countries. About 8.3 million people inhabit a territory which is about $42,000 \mathrm{~km}^{2}$ in area, though the largest part is uninhabitable due to the Alps. Most of the population is concentrated in the lower-lying areas called the Mittelland. About 25 per cent of the population is foreign, even though more than half of those without a Swiss passport were either born in Switzerland or have lived in the country for at least a decade. The foreign population largely comes either from European Union (EU) or from European Free Trade Association (EFTA) countries (e.g., Italy, Germany, Portugal).

The density of political units in the territory is striking, and includes 26 largely sovereign cantons and 2255 (as of 1 January 2017) relatively autonomous communities (for more on this, see Chap. 2). The large number of territorial sub-units means most of them are quite small, and that there is considerable variation in their population size. The smallest Swiss communities have less than 100 inhabitants; the largest cities hold several hundred thousand. The largest canton (Zurich) has more than a million inhabitants, while the smallest cantons (Appenzell Innerrhoden, Uri, Obwalden, and Glarus) are in the low ten thousands. In spite of these large differences, no asymmetries exist under public law, and all communities are formally equal to one another, as are all cantons. Pronounced decentralization and the large independence accorded to decentralized political units is a distinctive characteristic of Swiss political culture.

Also characteristic is Swiss cultural heterogeneity, particularly in terms of religion and language. About 70 per cent of the inhabitants belong to a Christian faith. Catholics form a majority of the permanent resident population in 11 cantons, while in seven others, they are less than 30 per cent. The proportions in the remaining eight cantons are less clear. ${ }^{4}$ Switzerland is also a multilingual country with four national languages: 63 per cent

\footnotetext{
${ }^{4}$ See Bundesamt für Statistik: Strukturerhebung der eidgenössischen Volkszählung 2015: Sprachen und Religionen.
} 
speak (Swiss-) German, 23 per cent speak French, 8 per cent speak Italian, and 0.5 per cent speak Romansh. English, Portuguese, and Albanian, each spoken by $3-5$ per cent, are also relatively common.

Cultural differences call for considerable efforts at integration on the part of both society and government. In cultural terms, this requires accepting a degree of diversity and by respecting and considering the concerns of minorities. As can be seen in the next section, the political institutions make an important contribution here. Switzerland also profits - especially if one adds economic capacity - from the fact that its cleavages do not line up but are instead cross-cutting. Thus, rather than having rich, Protestant, German-speaking cantons opposing poor, Catholic, French-speaking cantons, one instead has Protestant and Catholic, and economically stronger as well as economically weaker, cantons in both German-speaking and French-speaking parts of the country.

\subsection{The Model of the State and the Extent of State Activity}

Switzerland does not belong to the category of 'Scandinavian-style welfare states', and unlike Germany or Austria, it also does not clearly endorse the 'social market economy' model. If one looks at the ratio of government expenditures (33.6 per cent) or tax revenues (27.7 per cent) to GDP, ${ }^{5}$ then these are markedly lower than in most European countries and are more comparable with the values found for Australia and the US. ${ }^{6}$ Nevertheless, it would be a mistake to regard the Swiss model of the state as being that of 'minimal state'. The Swiss state in the nineteenth century, dominated by the Liberals (Freisinn, now FDP.Die Radikalen), was not a 'night-watchman state' (Gruner 1964) concerned only to guarantee enough scope for economic interests, providing the infrastructure for modern trade and making workers available. Within the 'extended family' of the Freisinnige at the time, one could find not only adherents of the Manchester School but Democrats and Radicals as well. The latter made efforts, first at the level of individual cantons, to pursue socially balanced fiscal and social policies based on social justice and the provision of bene-

\footnotetext{
${ }^{5}$ See Bundesamt für Statistik: Kennzahlen der öffentlichen Finanzen im internationalen Vergleich 2015.

${ }^{6}$ See OECD Economic Outlook 90, Annex Table 25: General government total outlays in per cent of nominal GDP.
} 
fits, including free public education and the founding of cantonal banks to provide cheap 'popular credit' ${ }^{7}$. Towards the end of the nineteenth century, not least as a consequence of the economic crises during the 1880s, the national government increasingly influenced the economic framework (Code of Obligations 1881; Copyright Act 1883; Trademark Protection Act 1890; Patent and Invention Law 1883) and took measures to protect vulnerable groups (the Factory Law; the promotion of vocational training; support provided for agriculture in 1884).

Swiss politics at the national level was always dominated by centreright, employer-friendly forces. It was only at the end of the 1950s that left-wing parties, along with the Catholic People's Party that had become more centrist, and then later, particularly with the help of the Greens, that it was possible to form majorities around certain topics. Earlier, certain cantons, and especially certain cities, achieved left-wing majorities, and in recent years, nearly all large Swiss cities have been dominated by coalitions of Social Democrats, Green and left-wing parties.

Economic peak associations played an important role early on in Switzerland. They were successful at convincing the national government to subsidize their association offices (e.g., general-secretariats) already by the late nineteenth century (Mach 2006: 273). Their political involvement was strengthened in particular by governmental interventions during the economic crises of the interwar period. Their middle-class-oriented economic policies were also expanded and strengthened through corporatist arrangements (Sozialpartnerschaft). A series of protectionist decisions-limiting imports, barriers to market access, measures to limit competition, binding collective agreements by private economic associations - and economic arrangements - price fixing, participation in production costs, or eased access to capital-worked to the benefit of a whole series of sectors (Linder 1983: 278 et seq.). The peak associations made use of the government not just to protect their interests, but themselves became implementers of governmental policies to protect the market (Ackermann and Steinemann 1981: 86 et seq.).

The Second World War intensified the nexus between government and economy, one which was eventually ratified through revisions made, in 1947, to various articles of the Swiss constitution that addressed the economy. The clause concerning the freedom of trade now included a

\footnotetext{
${ }^{7}$ See Linder (1983: 260 et seq.) on this, with the corresponding references to Gruner (1964).
} 
caveat giving the national government the power to pass measures against cartels (especially if they had socially or economically damaging effects), the power to 'preserve a healthy farming estate', and to protect those parts of the country which were economically threatened. In addition, associations were to be explicitly included in preparing as well as implementing laws, and the binding force of collective bargaining agreements was confirmed. Finally, more formally, what had been constitutional articles designed to combat crises were now changed into constitutional articles to promote the economy. ${ }^{8}$

The proximity of government to economy can be seen in the significance para-state organizations are awarded. ${ }^{9}$ Through its branch associations, the private sector is involved in helping formulate and implement government policies. Traditionally, such organizations had particular influence in agriculture but also in other economic sectors (see Farago and Kriesi 1986); para-state organizations take on important roles in implementing policy, in market regulation, or in organizing vocational education. Such strong interlinkage between government and economy in carrying out tasks is called 'neocorporatism' in the political science literature (Schmitter 1974).

In calculating the ratio of government expenditures to GDP, part of the expenditures for social insurance is not included. Similarly, when calculating tax revenues relative to GDP, certain compulsory costs which residents in Switzerland must pay-for example, for the occupational pension scheme (the 'second pillar') or for medical insurance-are not counted. In other countries, these costs, to a lesser or greater degree, are included in the taxes residents pay.

Therefore, the low values found for the ratio of government expenditure or tax revenue to GDP do not reflect a limited set of benefits or a particularly efficient provision of services but are to some degree the result of a differing structure for meeting government obligations. If one includes mandatory payments into the pension funds and mandatory medical insurance payments, for example, then the ratio of tax revenues to GDP would rise (by about ten percentage points) to a little over 40 per

\footnotetext{
${ }^{8}$ In the current Swiss constitution, economic associations are wholly integrated and noted in Art. 94-104 (Economy) as well as in Art. 110 (Labor).

${ }^{9} \mathrm{~A}$ parliamentary investigation carried out in 1983 found 232 para-state organizations, employing nearly 12,000 people, at the national level; the received one billion CHF in subsidies. These figures do not include health insurance funds or organizations devoted to the handicapped. See Germann (2002).
} 
cent. ${ }^{10}$ Similarly, social insurance costs not included in government expenditures account for an additional 10 per cent of GDP.

The history of the Swiss state, like that of other comparable states, is one of growth, increased differentiation, and shifting emphases. At the beginning, the primary goal was to secure independence externally (e.g., establish sovereignty) and to ensure domestic peace and security. Subsequently, rights to participate or co-determine were added, and civil liberties had to be guaranteed. It also became important to create the necessary preconditions for the economy to develop. These preconditions included lowering barriers to trade and increasing government commitments to expand infrastructure (transportation, energy) and education. Over time, the national government took on more tasks related to health care and social security as well. Crises and structural changes also meant that business cycle and economic policies increased in importance. Maintaining the natural environment and sustainable development have become governmental tasks only in the more recent past.

Increased governmental activity can be illustrated by public outlay figures. When the modern Swiss federal state began in 1850, total expenditures at federal, cantonal, and local levels were about 50 million Francs. The federal share of this was only about 10 per cent, or 4.5 million Francs (Weber 1969: 17), and the remainder was about equally divided between the other two levels (Guex 1998: 102). ${ }^{11}$ By 2014, this had risen to 207.6 billion Francs (Federal Finance Administration 2016: 5). Of this, federal or national outlays constituted 64.7 billion (25.5 per cent), cantonal 85.2 billion (32.6 per cent), and community outlays 46.4 billion (18.3 per cent) Francs. To this, one can add expenditures for social security of about 59.8 billion (23.6 per cent). ${ }^{12}$

However, increases in government expenditures relative to GDP did not do so linearly. Until the late 1950s, they increased more or less parallel

\footnotetext{
${ }^{10}$ See the answer of the Federal Council to the interpellation of Jean-Pierre Graber on 29 September 2011 (Curia Vista 11.3970).

${ }^{11}$ Cantonal and community expenditures in this era are very difficult to establish because the data is very spotty or available only for certain places (e.g., Zurich or Bern).

${ }^{12}$ If one adds these four sums together, one arrives at a value of more than 256 billion; these are gross expenditure figures. However, the national government transfers money to the social security system and to the cantons (transfer payments between the levels) which in turn record the money they pay out as expenditures (e.g., a 'duplicated' outlay). The totals do not include such duplications, but they are included in the calculation of the percentages.
} 
to economic activity, meaning the ratio of government expenditure to GDP remained both low and relatively stable. ${ }^{13}$ The 1960 s saw a significant expansion of government activity, and the average real growth rate, at all governmental levels, exceeded the growth rate of real GDP (Kirchgässner 2004: 2). At the beginning of the 1960s, government outlays at all three levels were still considerably under 20 per cent of GDP.

Outlays may be contrasted with income. Interestingly, and typically for Switzerland in international comparison, all three governmental levels control their own tax income, as well as raise their own income taxes. As they have taxing autonomy, cantons and communities set their own tax rates. The highest tax rates the national government can charge, however, as well as the level of the value-added tax, are set out in the Swiss constitution. ${ }^{14}$ The authority given to the national government to raise taxes is also laid out in the constitution, and has a (renewable) time limit. ${ }^{15}$ This constitutional anchor means, for example, that to raise the national tax rate requires amending the constitution, and hence also calls for the approval of both the people and the cantons. Only the national government levies a value-added tax, and in European comparison, it is at a relatively low level. The cantons participate, partly, in the tax revenues gathered by the national government.

National revenue in 2014 stood at about 65 billion Francs, and of that, tax revenue constituted 58 billion Francs (Federal Finance Administration 2016). Of that 20 billion Francs (32.9 per cent) were generated from the value-added tax and 18 billion $(28.5$ per cent) from direct federal tax. Direct income taxes play a rather larger role at the cantonal and community levels. Total cantonal income stands at about 83 billion Francs. Of that 43 billion ( 52 per cent) comes from tax revenue, with 31 billion of that coming in turn from the direct taxation of natural persons and 25 billion ( 30 per cent) from transfer payments. Total income at the community level is about 45 billion Francs, 27 billion ( 60 per cent) from tax income and 5 billion ( 11 per cent) from transfer payments.

\footnotetext{
${ }^{13}$ Following Tanzi and Schuknecht (2000: 6), the ratio of government expenditure to GDP in 1870 was about 16.5 per cent; in 1960 , it stood at 17.2 per cent.

${ }^{14}$ Article 128 of the Swiss Constitution sets the maximum tax rate at 11.5 per cent. Article 130 sets the normal value-added tax rate at 6.5 per cent, though has been raised to 8 per cent until the end of 2017.

${ }^{15}$ See the transitional stipulations for Articles 128 and 130. Currently, the constitution stipulates that permission to raise direct federal taxes, as well as to charge a value-added tax, will run out in 2035 .
} 
Switzerland is not just strongly decentralized. It also has a public sector, at least in the classic sense, which is relatively small. Certain tasks which elsewhere are the responsibility of the public sector have traditionally been provided in cooperation with private actors. This goes along with the idea that government, economy, and society need not be antagonistic. Switzerland is often characterized as a liberal variant of the neo-corporatist model (Katzenstein 1985).

\subsection{Political Institutions}

The political institutions help integrate different segments of the population as well as the regions, but also contribute to holding the country together and maintain the country's (considerable) political stability. These institutions enjoy broad support among Swiss, ensuring the legitimacy of political decisions and political actions taken.

Political observers agree ${ }^{16}$ that the three cornerstones of the political system are provided by federalism, 'concordance' - meaning all important political actors and interests are involved in the decision-making processand direct democracy. These factors are often cited as reasons for Swiss 'distinctiveness' if not its idiosyncrasy. ${ }^{17}$ What they have in common is that they all either serve to limit the exercise of power or they encourage the sharing of power. Federalism divides power between the federal and cantonal levels, as well as between the cantons, while the 'concordance' system divides power between the parties and interests, and direct democracy divides power between the authorities and the people.

\subsubsection{Federalism}

It has already been noted that a federalist solution was the only possible path to pursue when the Swiss nation-state was founded in 1848. The 26 cantons (called Stände in Swiss usage) each have their own parliaments, their own executives, their own courts and their own constitutions, though cantonal constitutions cannot be in contradiction to the Swiss national

\footnotetext{
${ }^{16}$ See Linder (2005), Kriesi and Trechsel (2008), and Vatter (2016).

${ }^{17}$ Some authors also refer to the 'militia' idea of volunteering one's time to perform political and social tasks communities need, an idea which is still widespread. Neutrality is also often cited, though both it and the 'militia' character of politics, while they exert influence over politics and administration, have a less pronounced institutional character than federalism, 'concordance', and direct democracy.
} 
constitution. Cantons implement national laws and directives but otherwise organize their own activities according to their own needs. They have considerable leeway, for example, in how they organize education and hospitals, in the area of culture, as well as with respect to the police. Each canton levies its own income and wealth taxes to finance its cantonal tasks.

Cantons also participate in political decision-making at the national level. The primary locus for this is the upper house of Parliament (Ständerat), in which each full canton has two seats. Additionally, cantons have a special status in the context of Swiss direct democracy (see below), but what is decisive is the principle that every proposed extension of powers at the national level must be approved by a majority of the cantons. Cantons also exercise influence when new laws are being drafted, at which time their representatives, as experts, are consulted. Finally, they play an important role in implementing policies decided at the national level, and in doing so, have some degree of freedom.

The hundreds of inter-cantonal agreements (Konkordate), many of which involve infrastructure arrangements, play a special role as do cantonal inter-ministerial meetings (e.g., of the finance ministers of all the cantons). There is also a Conference of Cantonal Governments whose goal is to coordinate political policies among the cantons. One goal of this Conference is to keep political tasks from drifting up to the national level and thereby diminishing the influence of the cantons.

Swiss federalism is noteworthy particularly for its readiness to accept, and respect, different kinds of solutions; it also has an explicitly competitive orientation. Unlike German federalism, there is no constitutionally based mandate to ensure that the same living conditions prevail throughout the country. The logic of Swiss federalism operates much more with an eye to ensuring minimal standards that are to be ensured with the help of a nationwide financial equalization scheme which in essence takes from the rich(er cantons) and gives to the poor(er cantons). Tax competition between cantons (and communities) leads to considerable variation in the tax burden on individuals.

A comprehensive reform designed to bring about greater financial equalization between economically strong and economically weak cantons came into effect at the beginning of 2008. As part of the new rules, certain tasks were unbundled, cantonal cooperation was reorganized, and cooperation between cantonal and national levels was reconfigured. Still, increasing centralization remains an issue, as more and more tasks call for uniform regulation, and some of the pressures to do so derive from inter- 
national rules formulated outside of Switzerland. Education, health, and social expenditures, which have grown significantly in recent years, pose additional challenges for the cantons. Large differences and the small size of some cantons make inter-cantonal cooperation increasingly important, with the result that decisions are increasingly taken by executives and administrators rather than by voters.

\subsubsection{Direct Democracy}

Another key element of the political system is provided by the extensive direct democratic tools at hand. All changes to the constitution, as well as accession of the country to collective security or international organizations, call for a mandatory referendum. Here, it is not enough to obtain a majority of the votes; a majority of the cantons must also be in favour. Citizens can also launch popular initiatives to alter the constitution, for which they must collect 100,000 signatures within 18 months of launching the proposal. For a popular initiative to be successful, a majority of the votes as well as a majority of the cantons are also needed. Finally, citizens can also launch a referendum, if they so wish, against a new law that has been passed, as well as against certain international treaties. To do so, 50,000 signatures need to be collected within 100 days. If no (simple) majority is reached, the existing law stands. Individual cantons can also launch initiatives, and eight cantons together can launch a so-called cantonal referendum, though both happen quite rarely.

Direct democracy in Switzerland goes back to the 1830s, when St Gallen and Basel-Land first introduced a veto right for voters (Kriesi and Trechsel 2008: 4). Proposed amendments to the constitution requiring the approval of voters and cantons triggered a mandatory referendum already as of 1848, and a limited and relatively complicated version of the right to launch an initiative was introduced then as well, with whose help one could demand a total revision of the constitution. The 1874 revised national constitution introduced an optional referendum for laws that had been passed; in 1891, the initiative for a partial revision of the constitution was also introduced. More recent important changes have included extending these direct democratic tools to cover foreign policy issues, understandable in light of the increasing importance of supranational associations and international treaties.

There is no doubt that the existence of the referendum mechanism slowed the expansion of tasks the government could undertake. A series of 
modernization and centralization proposals failed during the early years of the federal state, largely due to the opposition from Catholic and conservative cantons (Kölz 2004: 633). Otherwise too, the expansion of the state - and not least of the social welfare state-was relatively slow and remained at a low level (Linder 2005: 263 et seq.).

The threat of a popular referendum leads to the integration of the most significant political forces into the government, thereby contributing significantly to the third major element, 'concordance'. A referendum gives interest group associations, political parties, and other organized groups the chance to defeat unloved changes made to constitution or law. To prevent this, strong political parties are represented in the government and participate in formulating proposals. Hence, they are, at least morally, obligated to support the resulting formulations. Efforts are also generally undertaken to include legitimate arguments brought by the opponents of a proposal in order to make them 'referendum-immune' (Neidhart 1970). Witness the extensive consultations (Vernehmlassungsverfahren) with all the interested groups, cantons, and parties that form part of the legislative process. Those groups less well represented in the political system, however, can articulate their concerns through the popular initiative process, and thereby can also exert influence on politics and policy-making.

Direct democracy not only means that politicians must be more strongly attuned to the 'popular will' but it also means the citizens' will carries greater weight in the work of the public administration. In the end, proposed laws or changes must convince a majority of the citizens, making ballot box decisions particularly relevant to administrative activities. It may go too far to ascribe a 'citizen-orientation' to administrators that results from the use of such direct democratic tools, but it is true that the verdict reached by the voters has a different valence than instructions received from the government.

\subsubsection{The 'Concordance' System}

The term 'concordance'18 refers to the more or less willing inclusion of the most important parties in the executive, as well as the willingness to govern in common with changeing majorities. As a rule, all the largest parties are represented in the executive, whether this is at community, cantonal, or

\footnotetext{
${ }^{18}$ See Arend Lijphart's conceptualization of consensus democracy and division of power (Lijphart 1999).
} 
national levels. The Federal Council (Bundesrat), Switzerland's national executive, is composed of seven members who have equal status, and who not only come from the various regions of the country but also are members of the four largest political parties. The Federal Council makes decisions collegially, its members oriented to reaching a consensus which will allow policy to be carried out. Outwardly, individual members of this Council represent the collegial consensus which has been reached-even when it goes against their personal convictions or against the position of the political party they belong to. Unlike in other countries, there is no clear distinction between government and opposition in Switzerland. There is no single party, or a coalition of parties, which determines policy for the duration of a legislative period. Instead, the individual representatives of various parties craft temporary majorities; these may shift, depending upon the issue. The executives at the lower levels of the Swiss system function similarly; parliaments and commissions have shifting majorities, depending on the issue, and their major task is to find sufficient support, from whichever political direction it may come, to create a majority for a given proposal or policy or law.

The 'concordance' system does have certain indirect effects on administrative activity. Though individual departments are headed by the representatives of various political parties, the political orientation of a department overall is more heterogeneous than in a system where the post as head of an administrative unit is filled by a person representing the current party in power. Thus, top civil servants do not necessarily belong to the same party as the (nominal) head of their department. That does not mean that civil servants do not quickly learn which proposals are likely to find greater favour with their administrative superiors, but it does mean that there is room for differing positions and arguments. In the end, proposed projects need to not only find favour in the ranks of one's own political party but also convince other members of the executive as well as other parties; otherwise, they will not achieve majority support either in Parliament or among the voters.

Aside from these 'soft' effects of 'concordance' and direct democracy on administrative activity, one also finds quick direct implications. Political processes take their time until all the political hurdles have been taken, and the great challenge is to suggest proposals which will find majority support. These, inevitably, are the creatures of compromise, and may call for-sometimes quite costly-concessions to be made to the various stakeholders. 
The effects of federalism and community autonomy paired with the commitment to subsidiarity are even more dramatic and incisive. They lead to a pronounced segmentation, both horizontally and vertically. This makes it easier to take account of social and cultural differences, and to create much more homogeneous sub-units. However, the consequence, along with the considerable diversity it permits, is a small-scale partitioning of what is already a very small nation-state. Corporative networks between the various levels are needed if the many necessary tasks are to be fulfilled by government and administration, and it is not surprising that in many areas, and in many places, it has not been possible to establish professional administrative structures. As we will see in Chap. 2, governmental tasks have therefore had to be carried out with the aid of private sector organizations and the help of many ordinary citizens who, in what Swiss call a 'militia system', volunteer their time to help govern communities.

\section{REFERENCES}

Ackermann, C., \& Steinmann, W. (1981). Historische Aspekte der Trennung und Verflechtung von Staat und Gesellschaft in der Schweiz - die Genese der Verschränkung. Forschungsprojekt Parastaatliche Verwaltung, Projektbericht Nr. 14. ETH Zürich: ORL-Institut.

Denters, B., Ladner, A., Mouritzen, P. E., \& Rose, L. E. (2016). Reforming local governments in times of crisis: Values and expectations of good local governance in comparative perspective. In S. Kuhlmann \& G. Bouckaert (Eds.), Local public sector reforms in times of crisis: National trajectories and international comparisons (pp. 333-345). London, UK: Palgrave Macmillan.

Farago, P., \& Kriesi, H. (Eds.). (1986). Wirtschaftsverbünde in der Schweiz. Grütsch: Verlag Rüegger.

Federal Finance Administration. (2016). Finanzstatistik der Schweiz 2014. Zwischenbericht. Bern: Schweizerische Eidgenossenschaft.

Germann, R. E. (2002, December 18). Öffentlicher Haushalt. Historisches Lexikon der Schweiz. http://www.hls-dhs-dss.ch/textes/d/Dl0342.php. Accessed 7 May 2012.

Gruner, E. (1964). 100 Jahre Wirtschaftspolitik. Etappen des Interventionismus in der Schweiz. Schweizerische Zeitschrift für Volkswirtschaft und Statistik, 100 (I/II), 34-70.

Guex, S. (1998). L'argent de l'Etat-Parcours des finances publiques au XXème siècle. Lausanne: réalités sociales.

Katzenstein, P. J. (1985). Small states in world markets: Industrial policy in Europe. Ithaca: Cornell University Press. 
Kirchgässner, G. (2004). Die langfristige Entwicklung der Bundesfinanzen 1960-2002. Hintergrundpapier zu, 3. Teil des Jahresberichts 2004 der Kommission für Konjunkturfragen. Universität St. Gallen.

Kölz, A. (2004). Nenere schweizerische Verfassungsgeschichte. Ibre Grundlinien in Bund und Kantonen seit 1848. Bern: Stämpfli.

Kriesi, H., \& Trechsel, A. H. (2008). The politics of Switzerland. Continuity and change in a consensus democracy. Cambridge: Cambridge University Press.

Ladner, A. (2011). Die wichtigsten institutionellen Reformen zwischen 1970 und 2010 in Bund, Kantonen und Gemeinden: Welche Rolle spielt die konjunkturelle Lage? In N. Soguel (Ed.), Des politiques an chevet de la conjoncture (pp. 149-174). Lausanne: Presses polytechniques universitaires romandes.

Lijphart, A. (1999). Patterns of democracy. Government forms and performance in thirty-six countries. New Haven: Yale University Press.

Linder, W. (1983). Entwicklung, Strukturen und Funktionen des Wirtschafts- und Sozialstaats in der Schweiz. In A. Riklin (Ed.), Handbuch des politischen Systems der Schweiz, Band 1. Grundlagen (pp. 255-381). Bern: Haupt.

Linder, W. (2005). Schweizerische Demokratie. Institutionen, Prozesse, Perspektiven. Bern: Haupt.

Mach, A. (2006). Associations d'intérêts. In U. Klöti, P. Knoepfel, H. Kriesi, W. Linder, Y. Papadopoulos, \& P. Sciarini (Eds.), Handbuch der Schweizer Politik, 4th completely (revised ed., pp. 369-392). Zürich: Neue Zürcher Zeitung libro.

Maissen, T. (2010). Die Geschichte der Schweiz. Baden: Hier + jetzt.

Neidhart, L. (1970). Plebiszit und pluralitäre Demokratie. Eine Analyse der Funktion des schweizerischen Gesetzesreferendums. Bern: Francke.

Polli-Schönborn, M. (2006, November 6). Zölle. Historisches Lexikon der Schweiz. http://hls-dhs-dss.ch/textes/d/D13765.php. Accessed 30 May 2012.

Schmitter, P. (1974). Still the century of corporatism? Review of Politics, 36(1), $85-131$.

Tanzi, V., \& Schuknecht, L. (2000). Public spending in the 20th century: A global perspective. Cambridge: Cambridge University Press.

Vatter, A. (2016). Das politische System der Schweiz. Baden-Baden: Nomos UTB.

Weber, M. (1969). Geschichte der schweizerischen Bundesfinanzen. Bern: Haupt. 
Open Access This chapter is licensed under the terms of the Creative Commons Attribution 4.0 International License (http://creativecommons.org/licenses/ by $/ 4.0 /$ ), which permits use, sharing, adaptation, distribution and reproduction in any medium or format, as long as you give appropriate credit to the original author(s) and the source, provide a link to the Creative Commons license and indicate if changes were made.

The images or other third party material in this chapter are included in the chapter's Creative Commons license, unless indicated otherwise in a credit line to the material. If material is not included in the chapter's Creative Commons license and your intended use is not permitted by statutory regulation or exceeds the permitted use, you will need to obtain permission directly from the copyright holder.

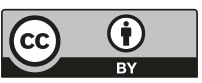

